\title{
Influence of bisphenol A on spermatological parameters of New Zealand White Rabbits
}

\author{
HAYRULLAH KARABULUT, MEHMET SUKRU GULAY*
}

\author{
Veterinarian, Burdur, Turkey \\ *Department of Physiology, Faculty of Veterinary Medicine, Burdur Mehmet Akif Ersoy University, Burdur, Turkey
}

\section{Influence of bisphenol A on spermatological parameters of New Zealand White Rabbits}

\section{Summary}

This study aimed to investigate the possible reproductive toxicity dose of bisphenol A (BPA) in male New Zealand white rabbits. Prior to the experiment, male rabbits $(n=24)$ were acclimatized to laboratory conditions and trained for semen collection for 14 days. After the training period, rabbits were divided into 4 groups of 6: positive controls and 3 different doses of BPA $(10,20$ and $100 \mathrm{mg} / \mathrm{kg} /$ day $)$. All treatments were administered by oral gavages for 9 weeks following the training period. At the end of the study, BPA negatively affected the serum testosterone, testicular superoxide dismutase (SOD), catalase (CAT), glutathione peroxidase (GPx) and malondialdehyde (MDA). Sperm concentrations and percent progressive motility were significantly declined in BPA treated rabbits. LOAEL value of BPA for reproductive parameters was $10 \mathrm{mg} / \mathrm{kg} / \mathrm{day}$.

Keywords: Bisphenol A, histopathology, oxidant-antioxidant enzymes, reproductive hormones, spermatologic parameters

Bisphenol A [BPA; 2,2-bis (4-hydroxyphenyl) propane] is one of the endocrine disrupting chemicals that has a very high production volume worldwide (15). BPA-based plastic products have been commercially produced since 1957 (22) and the demand is expected to be over 9.6 million tons by 2020 (14).

BPA is mainly used in the production of polycarbonate plastics and epoxy resins. They are extensively used in diverse products of daily life, including electronic and medical equipment, reusable bottles and water pipes. In addition, epoxy resins are used in the coating of the inner surfaces of food and beverage containers to prevent the reactions of the contents with metals $(16,19,38)$.

While BPA was first synthesized in 1891, its estrogenic properties were reported in the 1930s. BPA is one of the most important environmental estrogens that can be the basis of many negative effects such as cardiovascular diseases, immune disorders, obesity, diabetes, cancer and reproductive problems $(34,43)$.

There have been a number of different studies focused on the effects of BPA on spermatogenesis, reproductive hormone productions, and testicular cell activities in human and different animals. The results of the epidemiological studies suggested that increased urinary or serum BPA levels were likely to associate with reduced semen parameters (25). Experimental studies in animal models also suggested that BPA could reduce sperm count and sperm motility (41). BPA may be responsible for various negative effects such as deterioration in spermatogenesis, decrease in sperm quality, disturbing the hypothalamic-pituitarytesticular axis and decrease in testosterone production by Leydig cells (15).

As an endocrine disruptor, BPA has been receiving major attention, as to whether it impairs male fertility. However, the literature lacks BPA studies using rabbits as an experimental model. It is possible to take full ejaculate from male rabbits instead of epididymal spermatozoa, and so rabbits seem to be a better model for studying reproductive and toxicological effects of a chemical on spermatological parameters that can be related to man. Therefore, the aim of this study was to investigate the appropriate BPA dose and reproductive effects of BPA exposure in rabbits.

\section{Material and methods}

Animals and diets. This study was approved by the ethics committee of Burdur Mehmet Akif Ersoy University (25.11.2015/159) and supported by TUBITAK (116O027). During the entire experiment, a total of 24 male New Zealand White rabbits were individually housed in galvanized cages in the Experimental Animal Unit of Mehmet Akif Ersoy University and maximum care was taken to mini- 
mize the number of rabbits used. The ages and weights of the rabbits were $8-10$ months and $2.7-3.7 \mathrm{~kg}$, respectively. Prior to the experiment, the rabbits were trained to use an artificial vagina and acclimatized to laboratory conditions (at $22 \pm 2{ }^{\circ} \mathrm{C}$ and 50-55\% humidity, 14: 10 hour light: dark cycle) for 14 days.

Water and feed were given as ad libitum. The rabbits were fed with standard commercial rabbit feed (Korkuteli Food Company, Antalya, Turkey; 6.93\% crude ash, 17.0\% crude protein, $12.68 \%$ crude cellulose, $3.67 \%$ crude oil, $0.49 \%$ calcium, $0.46 \%$ phosphorous). Body weights and feed consumptions of the rabbits were taken weekly and dose adjustments of BPA were made according to their body weights.

Experimental design. After the acclimatization period, the rabbits were randomly divided into 4 groups of 6 rabbits in each group. Initial mean body weights and ages among the groups did not differ significantly. Rabbits in the control group (CONT) received daily corn oil by oral gavage for 9 weeks. Rabbits in BPA10, BPA20 and BPA100 groups were administered daily oral gavages of BPA (99\% purity, Lot: MKBQ5209V, CAS 80-05-7, Sigma-Aldrich Co., St. Louis, MO; 10, 20 and $100 \mathrm{mg} / \mathrm{kg} /$ day) dissolved in corn oil at doses of 10, 20 and $100 \mathrm{mg} / \mathrm{kg}$ body weight, respectively. Oral gavage practices were administered between 08:00 and 09:30 hours before daily feeding.

The study protocol in the groups used in the study of $\mathrm{BPA}$ is as follows:

CONT: Control group: daily oral corn oil (1 $\mathrm{ml}$ corn oil for $1 \mathrm{~kg}$ body weight);

BPA10: daily $10 \mathrm{mg} / \mathrm{kg}$ of BPA in corn oil (1 $\mathrm{ml}$ of corn oil contained $10 \mathrm{mg}$ of BPA);

BPA20: daily $20 \mathrm{mg} / \mathrm{kg}$ of BPA in corn oil (1 $\mathrm{ml}$ of corn oil contained $20 \mathrm{mg}$ of BPA);

BPA100: daily $100 \mathrm{mg} / \mathrm{kg}$ of BPA in corn oil (1 $\mathrm{ml}$ of corn oil contained $100 \mathrm{mg}$ of BPA).

Blood samples. At the end of the study, blood samples were collected from the ear artery of each rabbit. Blood samples were immediately centrifuged at $1457 \times \mathrm{g}$ for $20 \mathrm{~min}$ and serum samples were stored at $-20^{\circ} \mathrm{C}$ until analysis.

Semen collection and examination. The collection procedure was used as previously explained by Ata et al. (4). The ejaculates were collected into graded warm semen collection tubes once a week. Spermatological parameters were calculated with the sample taken at the end of the $9^{\text {th }}$ week to see the possible effects of BPA consumption. Immediately after the collection, the ejaculates were examined for semen volume, semen weight, semen $\mathrm{pH}$, sperm concentration and motility $(3,4)$.

Ejaculate volume and weight. Before the semen collection, the graduated semen collection tubes were weighed. After the collection, the gel from the ejaculate was removed and the tube was weighed to determine the ejaculate weight (mg). The ejaculate volume was recorded by reading the graded tube ( $\mathrm{ml})$.

Semen pH. Hydrogen ion concentration of the semen samples was measured immediately post collection by using $\mathrm{pH}$ paper ranging from 5.5 to 9.0 with 0.5 sensitive (pH-indicator paper $\mathrm{pH}$ 5.5-9.0 Merck, 64293, Darmstadt, Germany).
Spermatozoa concentration. The concentration of spermatozoa in each ejaculate was determined using a two-part hemocytometer slide (Thoma slides). The spermatozoa count was performed in Thoma slide with a magnification of 400-fold in $0.1 \mathrm{ml}$ formalin saline solution $(3,4)$.

Sperm motility. The motility estimations were performed by visual examination using a phase contrast microscope with a heating plate at medium magnification $(400 \times)$. Sperm samples were diluted 10-fold with phosphate-buffered saline (PBS) solution at $37.8^{\circ} \mathrm{C}$. After warming the slide to $37.8^{\circ} \mathrm{C}$, a small drop of diluted semen was placed on the slide and motility was estimated as percent at $400 \times$ magnification at phase contrast microscope $(3,4)$. In order to determine the motility, at least three microscope areas were evaluated. The average value of three different fields was recorded by detecting percent motility.

Seminal plasma protein levels. After collection, semen samples $(300 \mu \mathrm{L})$ were centrifuged at $800 \times \mathrm{g}$ for $20 \mathrm{~min}$. Then seminal plasma and the sperm cells were separated. $10 \mu \mathrm{L}$ of seminal plasma were placed into a refractometer (Atago, SPR-N, Japan) for the measurements of total seminal plasma protein readings.

Serum BPA analyses. Serum BPA levels were determined by the method of Kuroda et al. (23) The samples were analyzed by HPLC (LC-20AT, Shimadzu, Kyoto, Japan) within an accredited facility of the Burdur Mehmet Akif Ersoy University (MAKU, Scientific and Technology Application and Research Center, Burdur, Turkey). The detection limit of the method was $0.04 \mu \mathrm{g} / \mathrm{mL}$.

Hormone assays. Serum testosterone (Cat No CSBE06927Rb, Cusabio Biotech Co., LTD.; intra- and inter assay precision of $<15 \%$ and the detection range of 62.5 $-1000 \mathrm{pg} / \mathrm{mL}$ ) and estradiol (Cat No CSB-E069915Rb, Cusabio Biotech Co., LTD.; intra- and inter assay precision of $<15 \%$ and the detection range of $0.625-10 \mathrm{ng} / \mathrm{mL}$ ) levels were determined using rabbit specific ELISA kits. Serum samples of each rabbit were also analyzed for rabbit luteinizing hormone - LH (Cat No: SG-0004Rb, SinoGeneClon Biotech Co., Ltd.; intra- and inter assay precision of $<10 \%$ and the detection range of 3-100 $\mathrm{mIU} /$ $\mathrm{mL}$ ), rabbit follicle-stimulating hormone - FSH (Cat No: SG-0001Rb; SinoGeneClon Biotech Co., Ltd.; intra- and inter assay precision of $<10 \%$ and the detection range of 5-180 mIU/mL) and rabbit inhibin alpha - INHA (Cat No: SG-0015Rb; SinoGeneClon Biotech Co., Ltd.; intra- and inter assay precision of $<15 \%$ and the detection range of $33-2000 \mathrm{pg} / \mathrm{mL}$ ). Measurements were performed according to the manufacturer's instructions.

Histopathological examination. Three rabbits from each experimental group were randomly selected and euthanasied under isoflourine anesthesia. During necropsy, the right testicles were removed, washed with PBS and fixed in $10 \%$ formaldehyde. The tissues passed through routine followup procedure and were blocked in paraffin. The paraffin blocks were cut at a thickness of $5 \mu$. Then stained with hematoxylin-eosin and examined under light microscope.

Oxidant-antioxidant parameters. Testis tissues for oxidant and antioxidant parameters were prepared according to the manufacturer's instructions. Malondialdehyde - MDA (Cat No: SG-50252; SinoGeneClon Biotech Co., Ltd.; intra- 
and inter assay precision of $<10 \%$ and the detection range of 6-350 ng/mL), superoxidedismutase - SOD (Cat No: SG-0061Rb; intra- and inter assay precision of $<10 \%$ and the detection range of $30-1000 \mathrm{pg} / \mathrm{mL}$ ), catalase - CAT (Cat No: SG-50185;intra- and inter assay precision of $<10 \%$ and the detection range of $1-36 \mathrm{pg} / \mathrm{mL}$ ), and glutathione peroxidase - GPx (Cat No: SG-0120Rb,intra- and inter assay precision of $<10 \%$ and the detection range of 33-2000 pg/ $\mathrm{mL}$ ) levels of the samples were assayed using ELISA kits (SinoGeneClon Biotech Co., Ltd., China). The results were read at $450 \mathrm{~nm}$.

Statistical analyses. All values are given as mean \pm SD. PROC ANOVA procedure of the SAS statistical program was used for statistical evaluation. The individual means of treatments were compared with the Tukey test. In all statistical applications, the difference was considered significant when the difference among the groups was $\mathrm{P}<0.05$.

\section{Results and discussion}

During the study period, no clinical symptoms were observed in rabbits due to BPA treatments. Serum BPA levels were significantly different between the groups and increased according to the BPA levels administered to the rabbits $(\mathrm{KONT}=0.00 \pm 0.00$; $\mathrm{BPA} 10=0.24 \pm 0.02 ; \mathrm{BPA} 20=$ $0.58 \pm 0.09 ; \mathrm{BPA} 100=0.89 \pm 0.12$ $\mu \mathrm{g} / \mathrm{ml} ; \mathrm{P}<0.0001)$.

Serum levels of some reproductive hormones are in Table 1. Among the reproductive hormones studied, only the serum levels of testosterone were affected due to BPA treatment $(\mathrm{P}<0.04)$. Serum testosterone levels declined in all BPA groups when compared to the control levels. On the other hand, no significant changes observed in serum levels of estradiol, FSH, LH or inhibin among the treatment groups $(\mathrm{P}>0.1)$.

Ejaculate volume, ejaculate weight, ejaculate $\mathrm{pH}$, progressive motility, spermatozoa concentrations, and seminal plasma total protein levels are in Table 2. The results of the current study suggested that BPA did not alter the ejaculate volume, ejaculate weight, ejaculate $\mathrm{pH}$ and seminal plasma protein levels of BPA treated rabbits. On the other hand, BPA had significant negative effects on progressive motility and spermatozoa concentration in all BPA groups.

Values for some oxidant-antioxidant enzymes measured in testis \pm standard deviation tissues are in Table 3. When the control group and the BPA-administered groups were compared, the MDA level in the testis increased significantly in the BPA groups $(\mathrm{P}<0.001)$. In addition, the levels of antioxidant enzymes such as SOD and CAT in the testis of the rabbits decreased significantly in BPA treated groups when compared to the controls $(\mathrm{P}<0.001)$. GPx enzyme levels of BPA20 and BPA100 groups were significantly lower than the control and BPA10 groups $(\mathrm{P}<0.041)$.

The criteria of Jahan and his colleagues (20) were taken into consideration when examining the testis tissue. Thus, degeneration of Sertioli cells, shedding of germ cells, the amount of sperm in the tubule lumen and the width of the interstitium were evaluated. It was noticed in the testicular tissues of the BPA groups that a large part of the Sertioli cells was degenerated and absorbed into the lumen. Most of the basal cells disappeared. There was a decrease in the spermatozoa

Tab. 1. Effects of oral bisphenol A (BPA) administration on some reproductive hormones in male New Zealand White Rabbits $(n=6)$

\begin{tabular}{|l|c|c|c|c|c|}
\hline & CONT & \multicolumn{1}{|c|}{ BPA10 } & \multicolumn{1}{c|}{ BPA20 } & \multicolumn{1}{c|}{ BPA100 } & P \\
\hline Testosterone $(\mathrm{ng} / \mathrm{ml})$ & $4.81^{\mathrm{a}} \pm 0.54$ & $3.58^{\mathrm{b}} \pm 0.25$ & $3.56^{\mathrm{b}} \pm 0.46$ & $3.39^{\mathrm{b}} \pm 0.15$ & 0.038 \\
Estrogen $(\mathrm{pg} / \mathrm{ml})$ & $559.1 \pm 32.1$ & $544.1 \pm 65.3$ & $574.1 \pm 73.6$ & $521.2 \pm 38.4$ & 0.495 \\
Inhibin $(\mathrm{pg} / \mathrm{ml})$ & $95.75 \pm 1.12$ & $95.08 \pm 3.93$ & $96.34 \pm 3.71$ & $99.24 \pm 8.04$ & 0.712 \\
FSH $(\mathrm{mlU} / \mathrm{ml})$ & $9.87 \pm 1.12$ & $11.07 \pm 1.32$ & $10.14 \pm 2.23$ & $9.84 \pm 1.25$ & 0.568 \\
LH $(\mathrm{mlU} / \mathrm{ml})$ & $9.34 \pm 0.25$ & $9.50 \pm 0.21$ & $9.29 \pm 0.23$ & $9.35 \pm 0.13$ & 0.461 \\
\hline
\end{tabular}

Explanations: $\mathrm{CONT}=\mathrm{Control}$; BPA $10=10 \mathrm{mg} / \mathrm{kg} / \mathrm{day}$ BPA; BPA20 $=20 \mathrm{mg} / \mathrm{kg} / \mathrm{day}$ $\mathrm{BPA}$; BPA100 $=100 \mathrm{mg} / \mathrm{kg} /$ day BPA. Values have given as mean \pm standard deviation

Tab. 2. Effects of oral bisphenol A (BPA) administration on some spermatological parameters in male New Zealand White Rabbits $(n=6)$

\begin{tabular}{|l|r|r|r|r|c|}
\hline & \multicolumn{1}{|c|}{ CONT } & \multicolumn{1}{c|}{ BPA10 } & \multicolumn{1}{c|}{ BPA20 } & \multicolumn{1}{c|}{ BPA100 } & \multicolumn{1}{c|}{ P } \\
\hline Volume $(\mathrm{ml})$ & $0.8 \pm 0.16$ & $0.68 \pm 0.14$ & $0.68 \pm 0.26$ & $0.62 \pm 0.15$ & 0.166 \\
Weight $(\mathrm{mg})$ & $0.94 \pm 0.18$ & $0.74 \pm 0.15$ & $0.73 \pm 0.27$ & $0.70 \pm 0.18$ & 0.274 \\
Progressive Motility $(\%)$ & $76.0^{\mathrm{a}} \pm 4.18$ & $52.0^{\mathrm{b}} \pm 5.70$ & $43.0^{\mathrm{c}} \pm 6.70$ & $38.0^{\mathrm{c}} \pm 2.74$ & 0.001 \\
pH & $7.08 \pm 0.08$ & $7.08 \pm 0.09$ & $7.06 \pm 0.09$ & $7.06 \pm 0.11$ & 0.972 \\
Concentration $\left(\times 10^{6} / \mathrm{ml}\right)$ & $314.4^{\mathrm{a}} \pm 63.8$ & $227.6^{\mathrm{b}} \pm 46.6$ & $188.6^{\mathrm{b}} \pm 34.0$ & $186.6^{\mathrm{b}} \pm 88.8$ & 0.016 \\
SPP $(\mathrm{g} / \mathrm{dl})$ & $3.44 \pm 0.33$ & $3.36 \pm 0.21$ & $3.32 \pm 0.11$ & $3.28 \pm 0.78$ & 0.947 \\
\hline
\end{tabular}

Explanations: $\mathrm{CONT}=$ Control; BPA $10=10 \mathrm{mg} / \mathrm{kg} / \mathrm{day}$ BPA; BPA20 $=20 \mathrm{mg} / \mathrm{kg} / \mathrm{day}$ $\mathrm{BPA} ; \mathrm{BPA} 100=100 \mathrm{mg} / \mathrm{kg} /$ day BPA. SPP $=$ Seminal Plasma Protein. Values have given as mean \pm standard deviation

Tab. 3. Effects of oral bisphenol A (BPA) administration on some antioxidant parameters in the testis tissues of male New Zealand White Rabbits $(n=3)$

\begin{tabular}{|l|c|c|c|c|c|}
\hline & \multicolumn{1}{|c|}{ CONT } & \multicolumn{1}{c|}{ BPA10 } & \multicolumn{1}{c|}{ BPA20 } & \multicolumn{1}{c|}{ BPA100 } & \multicolumn{1}{c|}{ P } \\
\hline MDA $(\mathrm{ng} / \mathrm{ml})$ & $25.79^{\mathrm{a}} \pm 4.03$ & $39.39^{\mathrm{b}} \pm 4.41$ & $43.83^{\mathrm{bc}} \pm 8.34$ & $52.87^{\mathrm{c}} \pm 8.93$ & 0.001 \\
SOD $(\mathrm{pg} / \mathrm{ml})$ & $9.11^{\mathrm{a}} \pm 2.57$ & $6.24^{\mathrm{b}} \pm 1.26$ & $3.36^{\mathrm{c}} \pm 1.65$ & $3.82^{\mathrm{bc}} \pm 1.60$ & 0.001 \\
CAT $(\mathrm{pg} / \mathrm{ml})$ & $19.45^{\mathrm{a}} \pm 6.82$ & $12.64^{\mathrm{b}} \pm 1.91$ & $10.01^{\mathrm{bc}} \pm 4.83$ & $5.03^{\mathrm{c}} \pm 4.30$ & 0.002 \\
GPX $(\mathrm{pg} / \mathrm{ml})$ & $284.2^{\mathrm{a}} \pm 66.23$ & $247.2^{\mathrm{ab}} \pm 1.26$ & $186.0^{\mathrm{b}} \pm 56.92$ & $196.4^{\mathrm{b}} \pm 27.5$ & 0.041 \\
\hline
\end{tabular}

Explanations: $\mathrm{CONT}=\mathrm{Control}$; BPA10 $=10 \mathrm{mg} / \mathrm{kg} / \mathrm{day}$ BPA; BPA20 $=20 \mathrm{mg} / \mathrm{kg} / \mathrm{day}$ $\mathrm{BPA} ; \mathrm{BPA} 100=100 \mathrm{mg} / \mathrm{kg} /$ day BPA; MDA = malondialdehyde; $\mathrm{SOD}=$ superoxide dismutase; $\mathrm{CAT}=$ catalase $; \mathrm{GPX}=$ glutathione peroxidase. Values have given as mean 
Tab. 4. Histopathological changes in testicular tissues due to bisphenol A (BPA) treatments $(n=3)$

\begin{tabular}{|l|c|c|c|c|}
\hline & CONT & BPA10 & BPA20 & BPA100 \\
\hline $\begin{array}{l}\text { Decrease in the spermatozoa } \\
\text { number in the tubulus }\end{array}$ & $-(3 / 3)$ & $\begin{array}{c}+(1 / 3) \\
++(2 / 3)\end{array}$ & $\begin{array}{c}+(1 / 3) \\
++(1 / 3) \\
++(1 / 3)\end{array}$ & $\begin{array}{c}++(2 / 3) \\
+++(1 / 3)\end{array}$ \\
$\begin{array}{l}\text { seminiferus contortus lumen } \\
\text { Increase in the vacuolar }\end{array}$ & $\begin{array}{c}-(2 / 3) \\
+(1 / 3)\end{array}$ & $\begin{array}{c}+(2 / 3) \\
+(1 / 3)\end{array}$ & $\begin{array}{c}+(1 / 3) \\
++(1 / 3) \\
+++(1 / 3)\end{array}$ & $\begin{array}{c}++(2 / 3) \\
+++(1 / 3)\end{array}$ \\
\hline
\end{tabular}

Explanations: $\mathrm{CONT}=$ Control; BPA $10=10 \mathrm{mg} / \mathrm{kg} /$ day BPA; BPA20 = $20 \mathrm{mg} / \mathrm{kg} /$ day BPA; BPA100 = $100 \mathrm{mg} / \mathrm{kg} /$ day BPA; - Absent or minimal; + Mild; ++ Moderate; +++ Marked

number and an increase in the vacuolar degeneration (Tab. 4).

The decrease in sperm count and motile spermatozoa are important for sperm quality. The results of the current study indicated that even with the lowest oral exposure, with $0.24 \mu \mathrm{g} / \mathrm{ml}$ plasma levels of BPA, BPA reduced the spermatozoa concentration by approximately $24 \%$ in adult male rabbits. The decrease in concentration was even higher in BPA20 and 100 groups. Moreover, progressive motility was declined from $23 \%$ up to $50 \%$ as a dose-dependent manner for BPA treated rabbits compared to controls. A similar dose-dependent reduction in semen quality was observed in rats (7). Other experimental studies in mice (39) and rats $(27,30,32,40)$ also reported a decline in semen quality due to BPA exposure. Moreover, Li et al. reported an inverse correlation between semen quality and urinary BPA in BPA-exposed individuals (26). Exposure to BPA in adult males have reported an abnormal testicular function (35), reducing daily sperm production (31), suppression of testicular steroidogenesis (1) and spermatogenesis (32). Furthermore, there was a negative correlation between serum BPA levels of males and embryo quality, suggesting BPA might negatively affect the sperm quality (6). Although Ashby et al. (2) found no association between BPA exposure and sperm quality, the majority of the literature supports a negative connection.

The possible adverse impact of BPA on sperm quality could directly be on spermatogenesis (37). Spermatogenesis in seminiferous tubules is controlled by testosterone and FSH. Thus, the disturbances in testosterone and/or FSH levels could have an adverse effect on spermatogenesis (8). In the current study, although there were no changes in serum LH, FSH and inhibin levels, testosterone levels were declined due to BPA exposure. There are some contradictory results in the literature about the association between circulating testosterone levels and BPA. Hanaoka et al. presented evidence that BPA exposure caused an increase in testosterone levels (18). Ina a human study, workers exposed to BPA have been reported to have higher serum testosterone. Similarly, there was a positive association between BPA and androgens in adults (12) and in newborns (11). In another study, BPA did not change serum testosterone levels in male rats (13). However, there are also studies showing that BPA could suppress the plasma testosterone levels and cause adverse effects on spermatogenesis $(28,36)$. In addition, BPA also has anti-androgenic properties in the adult human testis tissues (9).

Nonylphenols could have an inhibitory effect on P450c17 enzyme which is necessary for testosterone synthesis in Leydig cell and the decrease of testosterone concentrations in BPA groups might be due to inhibition of P450c17 by BPA $(17,24)$. Local production of testosterone by Leydig cells was crucial for the continuity of spermatogenesis (29) and BPA treatment could impair the critical hormonal balances necessary for the steps of sperm production in the current study. No changes in FSH an LH levels due to BPA suggest that BPA might directly affect the functions of Leydig cells and cause a reduction in testosterone production (1).

Oxidative stress could be another factor for poor sperm quality due to BPA exposure. BPA could decrease the number of sperm and percent motility by stimulating oxidative stress and reduction of antioxidant enzymes (7). Enzymes such as SOD and CAT are intracellular enzymatic antioxidants responsible for the scavenging reactive oxygen species (ROS) such as hydrogen peroxide and free radicals. In addition, SOD forms the first line of defense against reactive oxygen species in the cells (33). In the current study, the levels of SOD, CAT, and GPx in the testis tissues of rabbits exposed to oral BPA were lower than those in the control group. This can typically be a result of increased lipid peroxidation due to oxidative stress. Moreover, BPA stimulates the generation of MDA in testis tissues (5) and testicular MDA concentrations were also altered due to BPA treatment in our study. The increase in MDA levels in the testicular tissue because of BPA exposure could be due to the production of more ROS and therefore, oxidative stress than normal as a result of BPA (42). Thus, BPA can increase ROS production by stimulating free radical formation in Male New Zealand rabbits and may lead to oxidative stress (7). Increased oxidative stress stimulated by BPA exposure could adversely affect enzymatic antioxidant defenses, increase oxidative damage in testicular tissue and/or sperm cells and thus negatively alter sperm development and/or survival.

The histopathological alterations due to BPA exposure could also be another factor affecting the negative changes in semen quality. Previous studies reported similar results that BPA could cause necrosis, seminiferous tubule degenerations or aplasia and giant cell formation (10). BPA increased the number of apoptotic cells in the seminiferous tubules (41). There is also another report that BPA reduces the diameter and thickness of the epithelium and the surface area the seminiferous tubules (21). In the current study, histopathological findings such as degeneration in seminiferous tubules, Sertoli and germ cell degradation, decreased sperm production, decrease in basal cells, 
and disorganized Sertoli cells due to BPA exposure substantiate the impaired spermatogenesis.

In conclusion, the present BPA study showed that LOAEL value of BPA for spermatologic parameters was $10 \mathrm{mg} / \mathrm{kg} /$ day $(0.24 \mu \mathrm{g} / \mathrm{ml}$ plasma $)$. Thus, oral BPA exposure for 9 weeks could alter the testosterone production and testicular oxidative status, cause oxidative stress, enhance testicular tissue degeneration and decrease spermatogenesis in New Zealand White rabbits.

\section{References}

1. Akingbemi B. T., Sottas C. M., Koulova A. I., Klinefelter G. R., Hardy M. P. Inhibition of testicular steroidogenesis by the xenoestrogen bisphenol A is associated with reduced pituitary luteinizing hormone secretion and decreased steroidogenic enzyme gene expression in rat Leydig cells. Endocrinology 2004, $145,592-603$.

2. Ashby J., Tinwell H., Lefevre P. A., Joiner R., Haseman J.: The effect on sperm production in adult Sprague-Dawley rats exposed by gavage to bisphenol a between postnatal days 91-97. Toxicol. Sci. 2003, 74, 129-138.

3. Ata A., Hatipoglu F. S., Yildiz-Gulay O., Gulay M. S.: Protective role of ascorbic acid on subacute sperm toxicity in male New Zealand white rabbits treated with endosulfan. Drug Chem. Toxicol. 2007, 30, 181-195.

4. Ata A., Yildiz-Gulay O., Gungor S., Balic A., Gulay M. S.: The effects of carob (Ceratonia Siliqua) bean extract on male New Zealand White rabbit semen. World Rabbit Sci. 2018, 26, 209-215.

5. Aydogan M., Korkmaz A., Barlas N., Kolankaya D.: Pro-oxidant effect of vitamin $\mathrm{C}$ coadministration with bisphenol $\mathrm{A}$, nonylphenol, and octylphenol on the reproductive tract of male rats. Drug Chem. Toxicol. 2010, 33, 193-203.

6. Bloom M. S., VomSaal F. S., Kim D., Taylor J. A., Lamb J. D., Fujimoto V. Y. Serum unconjugated bisphenol A concentrations in men may influence embryo quality indicators during in vitro fertilization. Environ. Toxicol. Pharmacol. 2011, 32, 319-323.

7. Chitra K. C., Latchoumycandane C., Mathur P. P.: Induction of oxidative stress by bisphenol A in the epididymal sperm of rats. Toxicology 2003, 185, 19-127.

8. Chowdhury A. K.: Dependence of testicular germ cells on hormones: a quantitative study in hypophysectomized testosterone-treated rats. J. Endocrinol. 1979, 82, 331-340.

9. Desdoits-Lethimonier C., Lesné L., Gaudriault P., Zalko D., Antignac J. P. Deceuninck Y., Platel C., Dejucq-Rainsford N., Mazaud-Guittot S., Jégou B.: Parallel assessment of the effects of bisphenol A and several of its analogs on the adult human testis. Human Reprod. 2017, 32, 1465-1473.

10. Fawzy E. I., El Makawy A. I., El-Bamby M. M., Elhamalawy H. O.: Improved effect of pumpkin seed oil against the bisphenol-A adverse effects in male mice. Toxicol. Reports 2018, 5, 857-863.

11. Fenichel P., Dechaux H., Harthe C., Gal J., Ferrari P., Pacini P., WagnerMahler K., Pugeat M., Brucker-Davis F.: Unconjugated bisphenol A cord blood levels in boys with descended or undescended testes. Human Reprod. 2012, 27, 983-990.

12. Galloway T., Cipelli R., Guralnik J., Ferrucci L., Bandinelli S., Corsi A. M., Money C., Mccormack P., Melzer D.: Daily bisphenol A excretion and associations with sex hormone concentrations: results from the In CHIANTI adult population study. Environ. Health Perspect. 2010, 118, 1603-1608.

13. Gámez J. M., Penalba R., Cardoso N., Ponzo O., Carbone S., Pandolfi M., Scacchi $S$., Reynoso R.: Low dose of bisphenol A impairs the reproductive axis of prepuberal male rats. J. Physiol. Biochem. 2014, 70, 239-246.

14. Gear R., Kendziorski J. A., Belcher S. M.: Effects of bisphenol A on incidence and severity of cardiac lesions in the NCTR-Sprague-Dawley rat: A CLARITYBPA study. Toxicol. Letter 2017, 275, 123-135.

15. Gonçalves G. D., Semprebon S. C., Biazi B. I., Mantovani M. S., Fernandes G. S. A.: Bisphenol A reduces testosterone production in TM3 Leydig cells independently of its effects on cell death and mitochondrial membrane potential. Reprod. Toxicol. 2018, 76, 26-34.

16. Hamdy H., Yahia D., Afifi S., Salem D. A.: Endocrine disruption induced by bisphenol A in young and adult female Sprague Dawley rats. Comp. Clin. Pathol. 2018, 27, 967-974

17. Han X. D., Tu Z. G., Gong Y., Shen S. N., Wang X. Y., Kang L. N., Hou Y. Y., Chenet J. $X$ : The toxic effects of nonylphenol on the reproductive system of male rats. Reprod. Toxicol. 2004, 19, 215-221.

18. Hanaoka T., Kawamura N., Hara K., Tsugane S.: Urinary bisphenol A and plasma hormone concentrations in male workers exposed to bisphenol A diglycidylether and mixed organic solvents. Occup. Environ. Med. 2002, 59, 625-628.

19. Huang Y. Q., Wong C. K., Zheng J. S., Bouwman H., Barra R., Wahlström B., Neretin L., Wong M. H.: Bisphenol A (BPA) in China: A review of sources, environmental levels, and potential human health impacts. Environ. Int. 2012, 42, 91-99.
20. Jahan S., Ain Q. U., Ullah H.: Therapeutic effects of quercetin against bisphenol A induced testicular damage in male Sprague Dawley rats. Syst. Biol. Reprod. Med. 2016, 62, 14-124.

21. Kazemi S., Feizi F., Aghapour F., Joorsaraee G. A., Moghadamnia A. A.: Histopathology and histomorphometric investigation of bisphenol a and nonylphenol on the male rat reproductive system. North. Am. J. Med. Sci. 2016, 8, 215-221.

22. Kim H. S., Kim Y. B., Choi D., Cheon Y. P., Lee S. H.: Hershberger assays for bisphenol-A and its substitute candidates. Dev. Reprod. 2017, 21, 441-448.

23. Kuroda N., Kinoshita Y., Sun Y., Wada M., Kishikawa N., Nakashima K., Makino T., Nakazawa H.: Measurement of bisphenol A levels in human blood serum and ascitic fluid by HPLC using a fluorescent labeling reagent. J. Pharm. Biomed. Anal. 2003, 30, 743-1749.

24. Laurenzana E. M., Balasubramanian G., Weis C., Blaydes B., Newbold R. R., Delclos $K$. B.: Effect of nonylphenol on serum testosterone levels and testicular steroidogenic enzyme activity in neonatal, pubertal, and adult rats. Chem. Biol. Interact. 2002, 139, 23-41.

25. Li D. K., Zhou Z., Miao M., He Y., Qing D., Wu T., Wang J., Weng X., Ferber J., Herrinton L. J., Zhu Q., Gao E., Yuan W.: Relationship Between Urine Bisphenol-A Level and Declining Male Sexual Function. J. Androl. 2010, 31, 500-506.

26. Li D. K., Zhou Z., Miao M., He Y., Wang J., Ferber J., Herrinton L. J., Gao E., Yuan $W$ : : Urine bisphenol-A (BPA) level in relation to semen quality. Fertil. Steril. 2011, 95, 625-630.

27. Liu C., Duan W., Li R., Xu S., Zhang L., Chen C., He M., Lu Y., Wu H., Pi H., Luo X., Zhang Y., Zhong M., Yu Z., Zhou Z.: Exposure to bisphenol A disrupts meiotic progression during spermatogenesis in adult rats through estrogen-like activity. Cell Death Dis. 2013, 4, e676.

28. Mendiola J., Jørgensen N., Andersson A. M., Calafat A. M., Ye X., Redmon J. B., Drobnis E. Z., Wang C., Sparks A., Thurston S. W., Liu F., Swan S. H.: Are environmental levels of bisphenol a associated with reproductive function in fertile men? Environ. Health Perspect. 2010, 118, 1286-1291.

29. O'Shaughnessy P. J.: Hormonal control of germ cell development and spermatogenesis. Seminars Cell Develop Biol. 2014, 29, 55-65.

30. Richter C. A., Birnbaum L. S., Farabollini F., Newbold R. R., Rubin B. S., Talsness C. E., Vandenbergh J. G., Walser-Kuntz D. R., VomSaal F. S.: In vivo effects of bisphenol A in laboratory rodent studies. Reprod. Toxicol. 2007, 24, 199-224.

31. Rochester J. R.: Bisphenol A and human health: a review of the literature. Reprod. Toxicol. 2013, 42, 132-155.

32. Salian S., Doshi T., Vanage G.: Perinatal exposure of rats to Bisphenol A affects fertility of male offspring-an overview. Reprod. Toxicol. 2011, 31, 359-362.

33. Sen S., Yadava N., Gershengorn M.: Manganese Superoxide Dismutase (MnSOD) and Catalase (CAT) Enhance Survival and Influence Differentiation of Human Bone Marrow-Derived Mesenchymal Stem Cells (MSCs). Arterios. Thrombos. Vascular Biol. 2010, 30, E278-E278.

34. Tarapore P., Hennessy M., Song D., Ying J., Ouyang B., Govindarajah V., Leung Y. K., Ho S. M.: High butter-fat diet and bisphenol A additively impair male rat spermatogenesis. Reprod. Toxicol. 2017, 68, 191-199.

35. Tinwell H., Haseman J., Lefevre P. A., Wallis N., Ashby J.: Normal sexual development of two strains of rat exposed in utero to low doses of bisphenol A. Toxicol. Sci. 2002, 68, 339-348.

36. Tohei A., Suda S., Taya K., Hashimoto T., Kogo H.: Bisphenol A inhibits testicular functions and increases luteinizing hormone secretion in adult male rats. Exp. Biol. Med. (Maywood). 2001, 226, 216-221.

37. Toyama Y., Suzuki-Toyota F., Maekawa M., Ito C.: Adverse effects of bispheno A to spermiogenesis in mice and rat. Arch. Histol. Cytol. 2004, 67, 373-381.

38. Vandenberg L. N., Hauser R. Marcus M. Olea N., Welshons W. V: Human exposure to bisphenol A (BPA). Reprod. Toxicol. 2007, 24, 139-177.

39. Vom Saal F. S., Cooke P. S., Buchanan D. L., Palanza P., Thayer K. A., Nagel $S$. C., Parmigiani S., Welshons $W . V$. : A physiologically based approach to the study of bisphenol A and other estrogenic chemicals on the size of reproductive organs, daily sperm production, and behavior. Toxicol. Indust. Health 1998, 14, 239-260.

40. Wisniewski P., Romano R. M., Kizys M. M. L., Oliveira K. C., Kasamatsu T., Giannocco G., Chiamolera M. I., Dias-Da-Silva M. R., Romano M. A.: Adult exposure to bisphenol A(BPA) in Wistar rats reduces sperm quality with disruption of the hypothalamic-pituitary-testicular axis. Toxicology 2015, 329, 1-9.

41. Yin L., Dai Y., Cui Z., Jiang X., Liu W. Han F. Lin A., Cao J., Liu J.: The regulation of cellular apoptosis by the ROS-triggered PERK/EIF $2 \alpha /$ chop pathway plays a vital role in bisphenol A-induced male reproductive toxicity. Toxicol. Appl. Pharmacol. 2017, 314, 98-108.

42. Yonar M. E., Yonar S. M., Coban M. Z., Eroglu M.: Antioxidant Effect of Propolis Against Exposure to Chromium in Cyprinus carpio. Environ. Toxicol. 2014, 29, 155-164.

43. Zhu W. J., Qiao J.: Male reproductive toxicity of bisphenol A. Zhonghua Nan Ke Xue. 2015, 21, 1026-1030.

Corresponding author: Prof. Dr. Mehmet Sukru GULAY; Burdur Mehmet Akif Ersoy University, Faculty of Veterinary Medicine, Department of Physiology, Istiklal Yerleskesi, Burdur, Turkey; e-mail: msgulay@mehmetakif.edu.tr 